\title{
小河内貯水池における出水に伴う水質状況の変化
}

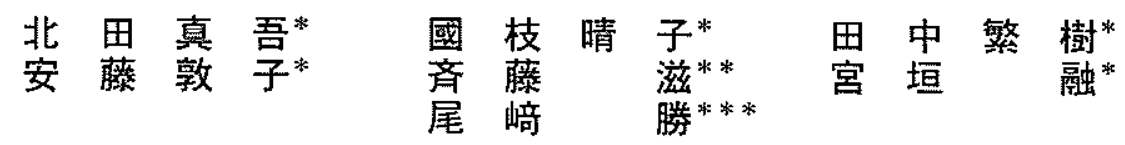

\section{Alteration of Water Quality in Ogouchi Reservoir Caused by Freshets}

\author{
Shingo KITADA*, Haruko KUNIEDA* , Shigeki TANAKA*, \\ Atsuko ANDOH*, Shigeru SAITOH**, Tohru MIYAGAKI* \\ and Masaru OZAKI***
}

\footnotetext{
* Water Quality Management Center, Bureau of Waterworks Tokyo Metropolitan Government, Hongou 2-7-1, Bunkyou-ku 113-0033, Japan * * Water Resources Administration Office, Bureau of Waterworks Tokyo Metropolitan Government, Urajuku 600 Oume 198-0088, Japan *** Bureau of Waterworks Tokyo Metropolitan Government, Nishi-shinjuku 2-8-1 Shinjuku-ku 163-8001 , Japan
}

\section{Abstract}

The Ogochi reservoir is one of the biggest dams for waterworks in Japan. We have been monitoring its water quality since its establishment. We introduced vertical curtains and some types of equipment in order to suppress algal blooms in the reservoir. The equipment showed suppressive effects against algal bloom expansion by suppressing the increase in surface temperature in the reservoir. An extensive flood in September 2007 induced a marked change in water quality. Because there was no turbidity before the flood, turbid water influx was observed in the depth range of $0-40 \mathrm{~m}$ near the dam. In the case of an extensive flood, it is necessary to operate the gates of the dam to form the secondary thermocline at an appropriate depth for discharging turbid water speedily.

Key words: reservoir, freshet, turbid water, nutrient

\section{1.はじめに}

東京都の水道水源は，利根川水系が約 8 割, 多摩川水系 が約 2 割である。多摩川水系の水源は, 水需要が增加する 夏季や利根川水系での水質事故時，渴水時などに活用する 貴重な水源である。小河内貯水池は，この多摩川上流に位 置し，東京都が所有する有效貯水量が 1 億 8540 万 $\mathrm{m}^{3}$, 有 効水深がダム堤体部付近で $101.5 \mathrm{~m}$, 水道専用としては国 内最大級のダム湖である。

小河内貯水池では, 平成 2 年以降, 蓝藻類による水の華 であるアオコが每年発生し, 平成13年には，ダム放流水か らカビ臭原因物質が検出されるようになった。そこで，昭 和 32 年の貯水池竣工以来実施してきた水質調查を強化す るとともに，アオコ抑制対策に着手した。水質センターで は，平成14年から水質調查の強化の一翼を担っている。

本報では, 平成19年に小河内貯水池を管理する水源管理 事務所と分担して実施した貯水池水質調盉の結果を報告 する。また, 平成19年には, 台風の襲来により多量の濁水 が貯水池へ流入したので，この濁水の挙動についても合わ せて報告する。

\section{2.これまでのアオコ抑制対策の経過}

小河内貯水池の集水域は，東京都奥多摩町，山梨県丹波 山村，小菅村及び甲州市の 4 市町村に及ぶ。主な流入河川 は，丹波川，後山川，小菅川，峰谷川の 4 河川で, 年間を 通じての平均的な流入量は，それぞれ約 $4 ， 1 ， 2 ， 0.5$ $\mathrm{m}^{3} \cdot \mathrm{s}^{-1}$ であり,これらが全流入量の約 9 割を占めている。 後山川を除いた 3 河川の上流には村落があり，栄坫盐類は 自然負荷と人為負荷が混在している。

一方, 夕゙ム放流水の水温が水辺のレジャ一等に適する水 温となるよう，平成 4 年以降 4 月から11月までの期間に貯 水池表面办ら水深数的の水を放流している（以下，「冷水 対策」という。）。近年，アオコの発生日数と発生規模が 年々增加する傾向にあることから，栄㵪塩類の流入負何や 冷水対策とアオコ発生との因果関係について榆討を進める とともに"1，この結果に基づいてアオコ抑制対筮を実施し ている。この効果の検証については，別途報告されている 2. 3)。

小河内貯水池におけるアオコ㓷制策は, Fig. 1に示すと おり，(1)分画フェンスの設置，(2)表層水移送装置の設置， (3)玲水対策における放流水深の微調整の 3 点である。

\footnotetext{
* 東京都水道局水筫センター $=113-0033$ 東京都文京区本拫 2-7-1

** 東京都水道局水源管理事務所

****東京都水道局 于163-8001 東索都新宿区西新缩 2-8-1
} 


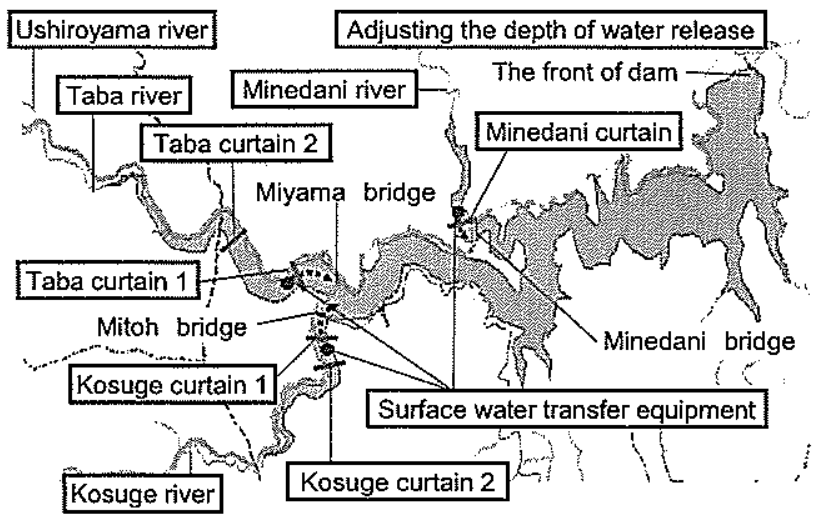

Fig.1 Ogouchi reservoir and locations of equipments against algal bloom

分画フェンスの概要を, Fig. 2に示す。分画フェンスは, 貯水池を涉断するように水面から垂下することで, アオコ の流下抑制あるいはアオコ形成域の狭小化を企図するも のである。小河内貯水池では，藍藻類が増殖する起点は， 河川流入部の上流部分であることが確認されていること から, 丹波川及び小菅川, 峰谷川の各流入部に水面から哚

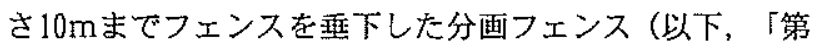
1 フェンス」という。）客 1 基，平成15年に設置した。 さらに，平成17年には，丹波第 1 フエンス及び小管 1 第 エンスの上流側には水面から深さ $2 \mathrm{~m}$ までフェンスを垂 下した分画フェンス（以下，「第 2 フェンスという。） を 1 基ずつ設置している。

表尿水移送装置の概要をFig.3に示す。表楞水移送装籔は, 貯水池表層に浮遊するアオコ栏成藍藻類を貯水池表面か ら水深 $1 \mathrm{~m}$ 程度までの水とともに吸入して貯水池中劂へ 移送することで, アオコ状態の解消を企図するものである。 この装犆は, 平成16年から設琶を進め, 現在は, 丹波川及 び小菅川, 峰谷川の流入部に処理水量 $2,000 \mathrm{~m}^{3} \cdot \mathrm{h}^{-1}$ の装置 を各 1 基導入している。装置の吸入口は第 1 フェンスの上 流倒約 $100 \mathrm{~m}$ 地点, 吐出口は满水面から水深 $40 \mathrm{~m}$ （貯水位 $60 \mathrm{~m}$ ) 程度となる地点 (吸入口から400～600 m下流の湖底） である。装置は，9月上旬の出水直後を除き，6月から10 月まで連続運転した。

放流水温の低下を抑えながら放流水深の微調整を図る ことにより，流入河川水中の栄羡塩類を眝水池から迅速に 排除する取り組みを行っている。

これらの対応により，アオコの発生は，平成16年から縮 小傾向に転じている ${ }^{3)}$ 。

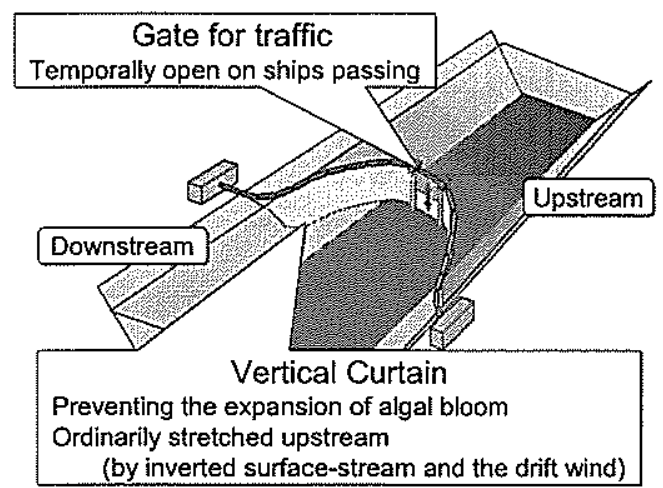

Fig.2 Vertical Curtain

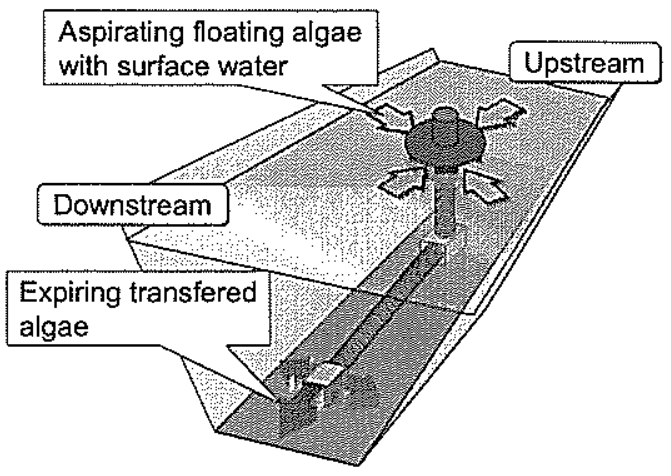

Fig.3 Surface water transfer equipment

\section{3. 平成19年調査の結果と考察}

\section{1 眝水位, 流入睼等}

眝水位及び流入量の推移をFig. 4に示す。貯水位は概ね $95 \mathrm{~m}$ 前後（貯水率で $80 \%$ から $90 \%$ 程度）で推移した。台風 等による多量な河川水の流入（以下，「出水」という。） は，7月中旬，7月下旬，9月上旬，10月下旬の 4 回発生 している。特に，9月上旬の出水は既往最大規模で, 流入 量の合計は約 1 譩的3であった。これは, 貯水量の約 7 割 が入れ替わる水量に相当する。この出水の際，小䒯第 1 フ エンスと峰谷フェンスは, 流入量が設定值を超えたことか ら安全装置が僛き，切り離しを行っている。また，ダム施 設の安全を確保するため, 流入量に合わせて㗨急放流を行 つている。なお，㗨急放流が行える貯水位は， $95 \mathrm{~m}$ 以上で ある。

\section{2 水温分布}

ダム前の鉛直水温分布及び水温躍層の推移をFig. 5に示 す。水温躍層は, 水温鉛直分布のなかで水温が急激に変化

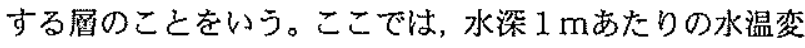
化が $1{ }^{\circ} \mathrm{C}$ 以上のものを「水温躍層」之呼び, $0.5^{\circ} \mathrm{C} ら 1$ ${ }^{\circ} \mathrm{C}$ ものを「弱い水温躍層」と呼ぶこととする。貯水位 60 $\mathrm{m}$ 程度以樑の水温は, 12 月末まで $10^{\circ} \mathrm{C}$ 末満であるが, 表層 の水温は, 8 月には $25^{\circ} \mathrm{C}$ 超え, 最高 $27.4^{\circ} \mathrm{C}$ 達している。 水温躍盗は, 最大で 3 段形成されていることが分かる。1 段目の水温躍屠は水深 $5 \mathrm{~m}$ から $10 \mathrm{~m}$ 程度（以下，「1 次躍 層」という。），2段目の水温躍層は水深 $15 \mathrm{~m}$ から $30 \mathrm{~m}$ 程 度（以下，「2次躍層」という。），3段目の水温躍層は 水深 $35 \mathrm{~m}$ か $540 \mathrm{~m}$ 程度 (以下, 「3 次躍層」という。) に 形成している。

2 次躍層は，7月中旬及び9月上旬の出水の影望を受け， 形成状況が変化している。7月中旬の出水後, 1 次躍層と 2 次躍層に挟まれる層が厚くなり，2次躍尿がより深い水 深に形成されている。一方，9月上旬の出水後は，1次踓 層と 2 次躍層に挟まれる首が厚くなるばかりでなく，2次 躍層が徐々に消滅している。3次躍層の形成水深は，表層 水移送装置昍出口の設遗水深之概小同程度である。

年間を通じて平均的な流量となっている時期 (以下, 「平 水時」という。）における河川流入部の水温維断分布を Fig. 6に示す。1 次躍層は, フェンス下流例では水深 $5 \mathrm{~m}$ 程度であるのに対して, フェンス上流側では水深 $1 \mathrm{~m}$ 程度 に形成されており, 分画フェンスと表尿水移送装罝の相乘 効果 ${ }^{3)}$ によって，第 1 フェンス上流倒の水温が下流側の水 温に比ベて低く保たれていることが確認された。また，丹 


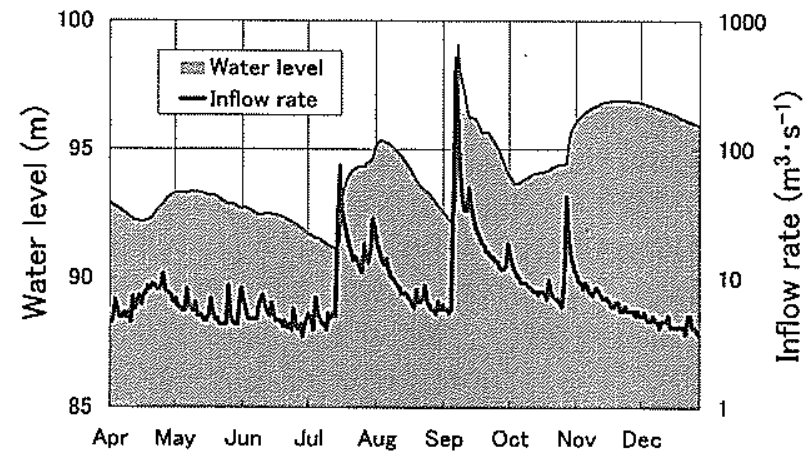

Fig. 4 Seasonal variation of water level and the inflow rate (2007)

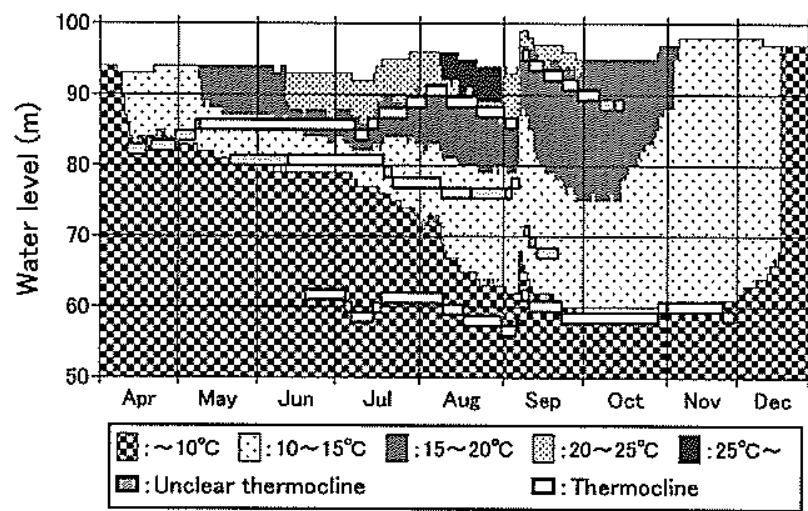

Fig.5 Seasonal variation of water temperature at the point in front of the dam (2007)

Distance from the front of dam $(\mathrm{km})$

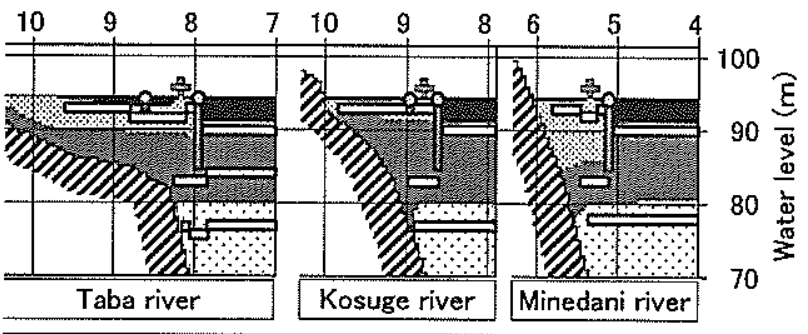

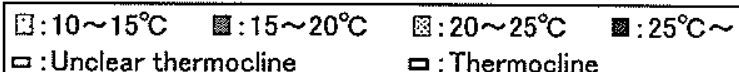

:Surface water transfer

Fig.6 Profile of water temperature at the influx points in summer season (14th Aug)

波第 2 フェンス付近における1 次躍層の形成水樑は, 丹波 第 1 フェンス值上流では $1 \mathrm{~m}$ 程度であるのに対し，2 から $4 \mathrm{~m}$ 程度とより染くなっていた。丹波第 1 フェンス及び小 菅第 1 フェンスの上流域においては, 日中に表層で発生す る上流へ向から流れ ${ }^{3,4)}$ により，表層の温かい水が第 2 フ エンスの下流側近傍に集められているものと考えられる。

貯水池等の表面水温が2 $25^{\circ} \mathrm{C}$ 程度以上になるとアオコが

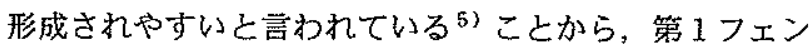
スの上下流において貯水池表面の水温が $25^{\circ} \mathrm{C}$ 以上になる 期間を比較した。結果をFig. 7に示す。水温が25ㄷ る期間は,フェンスの下流域では40日程度であるのに対し, フェンスの上流域では丹波川流入部で20日程度, 小菅川及 び峰谷川流入部では10日程度であった。
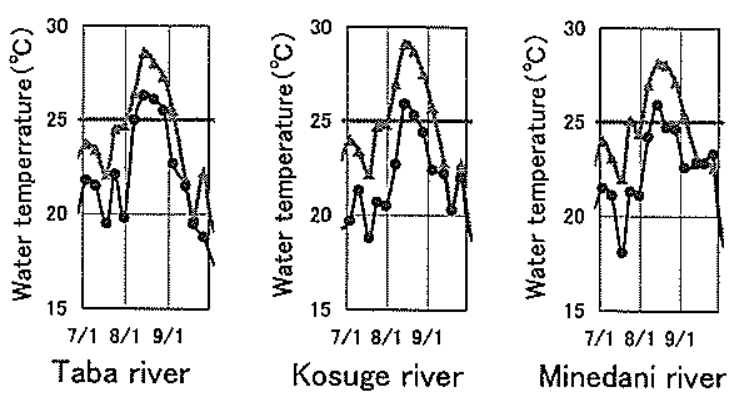

: Downstream side of the curtain
- : Upstream side of the curtain

Fig.7 Surface water temperature near the curtains (2007)

河川流入部に架かる橋梁地点における鉛直水温分布及 び水温趽層の推移をFig. 8に示す。これらの地点では，ダ 厶前とは異なり，8月中旬から9月上旬にかけて1次躍 層と 2 次躍層の間に新たな水温躍層（以下，「1.5次躍層」 という。) が形成され，最大 4 段の水温蹓層が形成されて いる(眝水位 $60 \mathrm{~m}$ 程度に形成されている 3 次躍層は, 紙面 の関係から省略した）。この 1.5 次躍層は，7月中旬の出 水前における 2 次躍層と概衫同程度の水深に形成されて いた。

\section{3 濁度分布}

ダム前の鉛㨁濁度分布をFig. 9に示す。7月中旬の出水 直後を除き，8月末頃までは，全層に渡り 3 度程度以下で あった。しかし， 9 月上旬の出水後には，3次䠊層相当水 媣まで 100 度以上の濁水が流入した。この濁水は，水温躍 層の消滅とともに拡散し, 平成19年12月末現在も一部が残 留している。

\section{4 藻類発生状況}

ダム前及び河川流入部における藻類の発生状況を Fig.10に示す。6月中は珠藻類が，7月から8月は緑藻類 が目立つが，9月以降はその他の藻類の比率が高くなって いる。アオコ非成藍藻類のアナベナ, ミクロキスチスは, 主に8月中旬に小菅川流入部で検出されているが, アオコ 形成には至らなかった。これは，第1フェンス上流側の唄 水池表面の水温が下流例よりも低く捚えられたことによ り，藍藻類が増殖できる期間を短くすることができたこと 等によるものと考えられる。

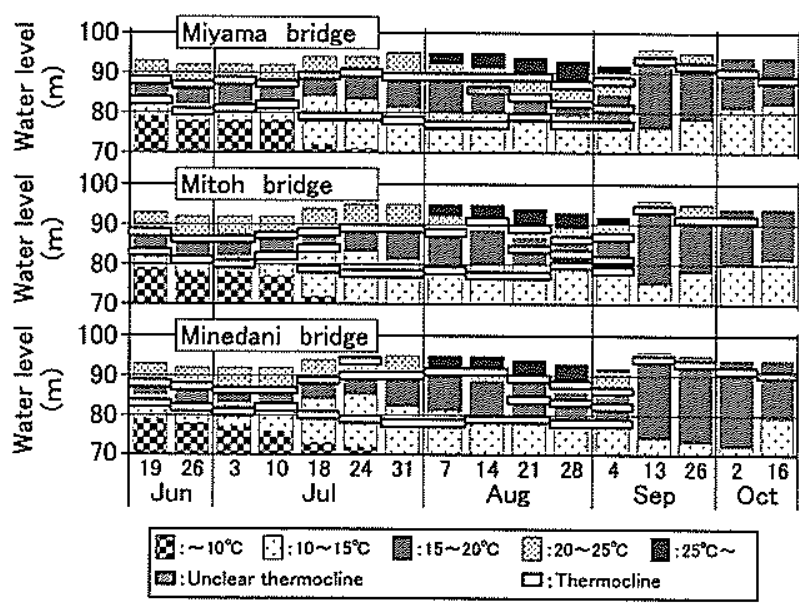

Fig.8 Water temperature at the influx points (2007) 


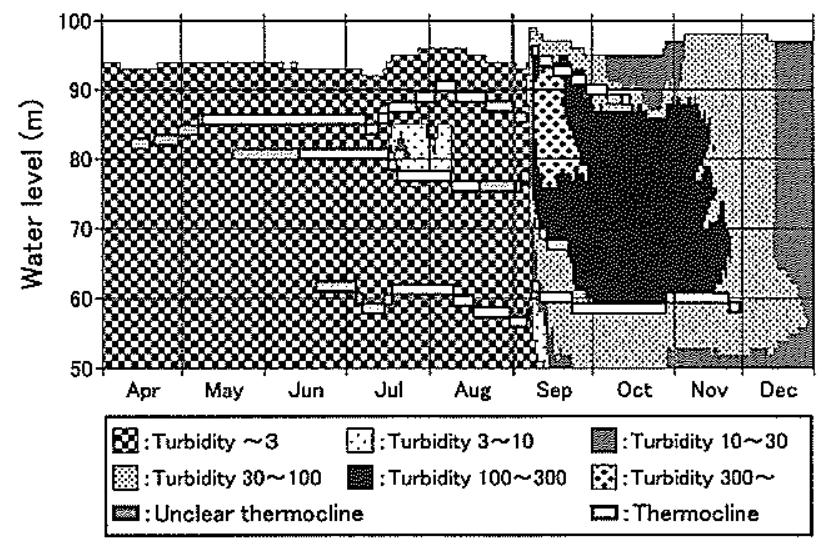

Fig.9 Seasonal variation of turbidity at the point in front of the dam (2007)
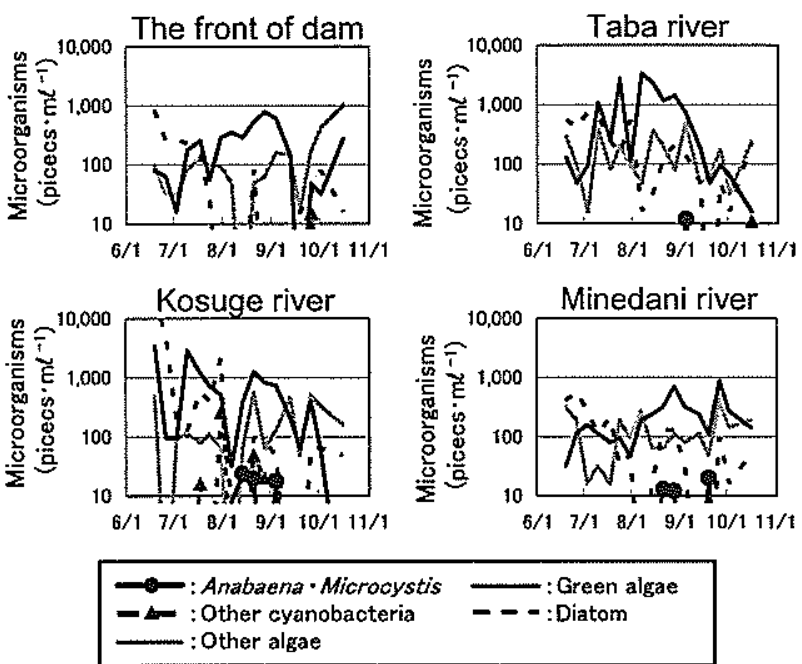

Fig.10 Enumeration of phytoplankton in summer (2007)

\section{5 カビ臭原因物啠検出状況}

カビ臭原因物質の検出状況をFig. 11に示す。カビ臬は， 8 月上旬に小管川流入部で検出され，8月中旬に $80 \mathrm{ng} \cdot \ell^{-1}$ を記録したのち, 減少傾向に転じた。他の河川流入部でも 小菅川流入部に遅れて㭘出されるようになったが,ダム前 では検出されなかった。カビ臬原因物質は，9月上旬以降 は，出水により押し流されたものと推定される。

\section{4. 出水に伴う濁犋の大量流入とその後の経過}

平成19年の出水汶，7月中旬，7月下旬，9月上旬及び 10 月下旬の 4 回発生しているが，比較的規模の大きかった?

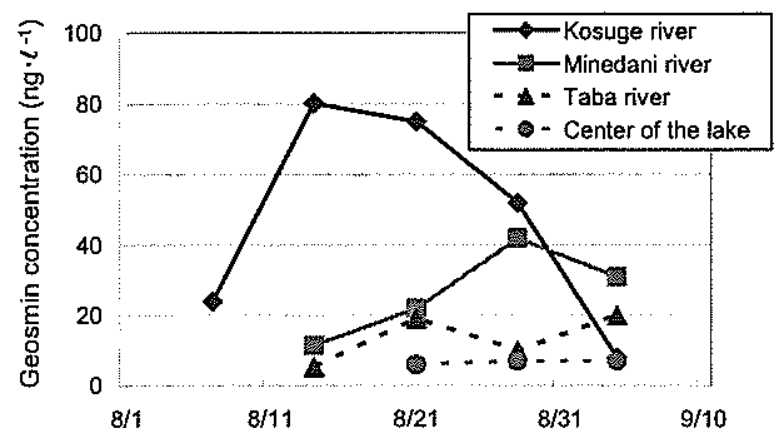

Fig.11 Concentration of geosmin in summer (2007)
月中旬と 9 月上旬の出水について，䍖度分布と栄羞塩類の 分布について詳しく述べる。

\section{17 月中旬の出水に伴う貯水池水䓄状況の変化}

7 月中旬の出水後約 1 ケ月経過した㭙点における河川 流入部の水温分布をFig. 12に示す。いずれの河川流入部で も，水梁 $10 \mathrm{~m}$ から $12 \mathrm{~m}$ ，すなわち第 1 フェンス下端の直下 $1 \mathrm{~m}$ 程度に1.5次躍層が形成され，これが第 1 フェンスの 上流側は $100 \mathrm{~m}$ 程度以上，第 1 フェンスの下流側は湖心部 まで広がっている。この㭙点における流入水温と1.5次躍 層の上側直近の水温は,いずれも $18^{\circ} \mathrm{C}$ 程度であった。また， 1.5次躍層の形成は, Fig. 8に示したとおり, 出水後 1 ケ月 程度経過した時点でも見られる。このことから，1.5次躇 層は，河川流入水が館水池内を流下する際，その下側の層 との境界面として形成されていることが示唆され，Fig. 12 に示す状況は，河川流入水が第 1 フエンスの少なくとも $100 \mathrm{~m}$ 上流で水深 $10 \mathrm{~m}$ から $12 \mathrm{~m}$ 程度を流下するように流れ を変えている可能性を示陵するものであると考えられる。

7 月中旬の出水後における濁度縦断分布をFig. 13に示 す。比較的高い濁度を示しているのは，丹波第1フェンス と丹波第 2 フェンスに挟まれた区間の水㳭 $5 \mathrm{~m}$ 程度の部 分及び第 1 フェンスからタ厶前までの水深 $10 \mathrm{~m}$ 程度の部 分である。このことから，7月中旬の出水によって流入し

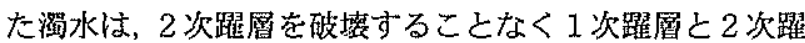

Distance from the front of dam $(\mathrm{km})$

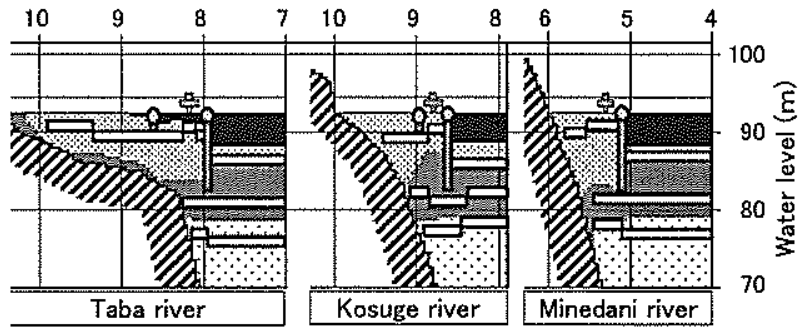

G: $10 \sim 15^{\circ} \mathrm{C}$ 图: $15 \sim 20^{\circ} \mathrm{C}$ 圆: $20 \sim 25^{\circ} \mathrm{C}$ 圆: $25^{\circ} \mathrm{C} \sim$ $\square$ : Unclear thermocline

\% : Surface water transfer equipment

Fig.12 Profile of water temperature at the influx points in summer (28th Aug)

Distance from the front of dam $(\mathrm{km})$

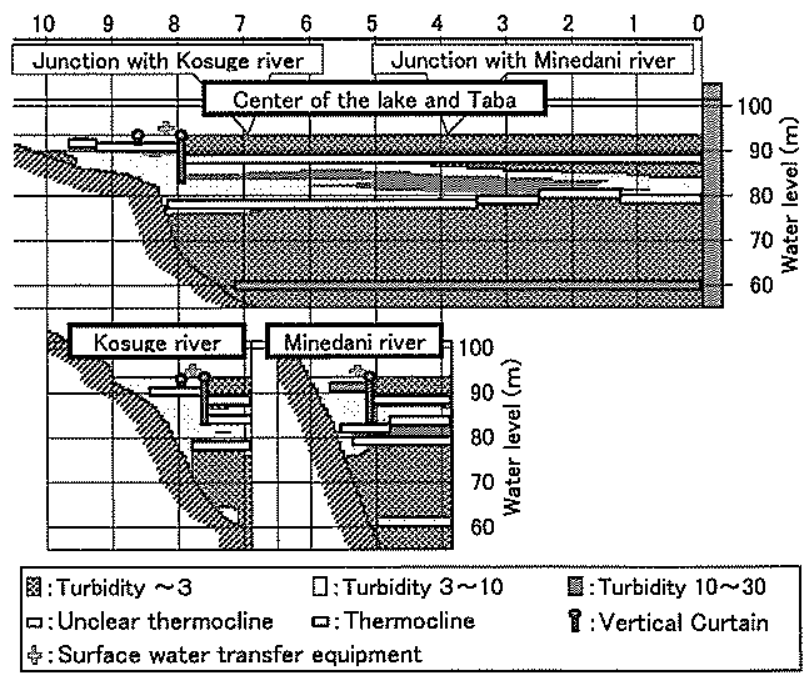

Fig.13 Profile of turbidity after the small freshet (18th Jul) 
層の間を流下していることが示唆された。これは, Fig. 9 に示したとおり，䝪水池の濁度状況が迅速に回復している ことからも推測できる。また, 濁質の分布状況から, 河川 流入部には, 流入端から第 1 フエンスに達する水深 $5 \mathrm{~m}$ 程 度の流れがあり，第1フェンス付近で稳やかな下降流が発 生していることも考えられる。

以上のことから，河川流入部において，河川流入水は Fig. 14に示すように流動している可能性が示唆された。平 成18年度に実施したコンピュータによる水質シミュレー ション調查の結果でも，このような 2 層に分かれる流れが 発生する可能性が示唆されている。濁度分布から導き出さ れる湖水の流れが実際に存在し，かつ，アオコ形成藍藻類 が流入端でその流れに連行されていると仮定すると, 平成 16年に行った調查の結果のとおりアオコ形成域が第 1 フ エンス上流側に限定されていたことが説明できる。すなわ ち, アオコ形成藍藻類には浮上性があることから, 流入端 から流下する過程で徐々に浮上していくとともに, 第 17 エンス付近の緩やかな下降流には連行されず, 表層に浮上 することでフェンス下流側へ流出する可能性はほとんど なくなり、フエンス上流側に集䄼するからであると考えら れる。今後, 河川流入部において湖水の流動と藻類の挙動 に関する詳しい調査が必要と考えられる。

2 次躍層あるいは 1.5 次䠰層の形成水深は, 流入河川水 の水温, 貯水池水温分布, 取水口水梁等に依存しており, 出水によって貯水池の水温分布が乱さ机ても, 台風による 出水は比較的高水温期に発生することから, 平水状態へ戻 る過程で取水口水深にあわせた水深に水温躍層が新たに 形成されると考えられる。また, 河川流入水は, 2次躍層 の上面に沿って 1 次躍層と 2 次躍層の間を流れると考元 られる。このことから, 冷水対策の観点から放流水温の低 下に留意する必要はあるが，出水時の流入量を勘案して， 適切な水梁に水温躍層を形成できるよう取水口水深を設 定して強固な 2 次暇層を形成させることで, 台風後の水質 回復の迅速化が図れる可能性があると考えられる。

\section{29 月上旬の出水に伴う貯水池水質状況の变化}

流入量が既往最大規模であった 9 月上旬の出水によっ て流入した濁水は, 1 次躍層と 2 次躍層に挟まれた層の容 積に対して流入量が極めて多かった。このため, Fig. 15に 示すとおり，2 次躍層の形成水深を押し下げるとともに躍 層そのものを不鮮明にし, さらに 2 次躍層と 3 次躍層に挟 まれた層へも流入したと考えられる。濁水の迅速排除のた

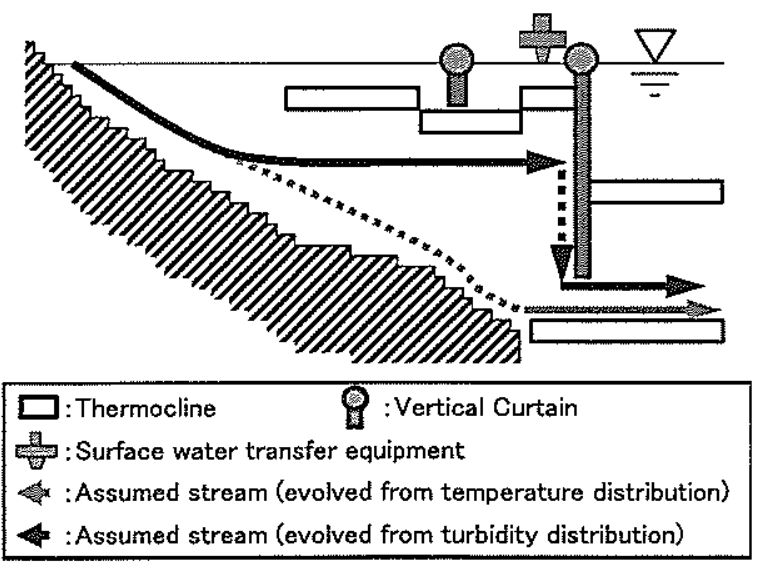

Fig.14 Enlarged view of the vertical curtain area
め, 放流量の増加や第 2 取水施設の運用期間延長などによ つて対応してきたが，前述のとおり，19年12月末現在も貯 水池内に渇水の一部が残留している。䀺水と栄羡塩類であ る総りンの分布には相関がある6)ことから, 平成20年の 春季以降, 水温の上昇に伴って藻類の異常增殖を引き起こ 寸可能性がある状況となっている。今後も，貯水池の水質 状況を注視していく必要がある。

平水時にお汀る栄盖塭類の検出状況は, 過去の調查でお おむね明確になっているが"，出水時における栄氺塩類 の分布については，詳細な調盉が行えず，これまで明確で なかった。9月上旬の出水から約10日経過した時点にお汀 る総リン及びリン酸態リンの縦断分布をFig. 16及びFig. 17に示す。総リンは, 湖心部下流部分及び峰谷川流入部の 水深 $15 \mathrm{~m}$ から $20 \mathrm{~m}$ 程度を中心に高濃度で分布している。 方, リン酸梽リンは総リンの分布傾向とは異なり, 今回の 台風による出水時のように藻類がほとんど存在していな いと考えられる状況下では, 湖心部上流部分及び小蒀川流

Distance from the front of dam $(\mathrm{km})$

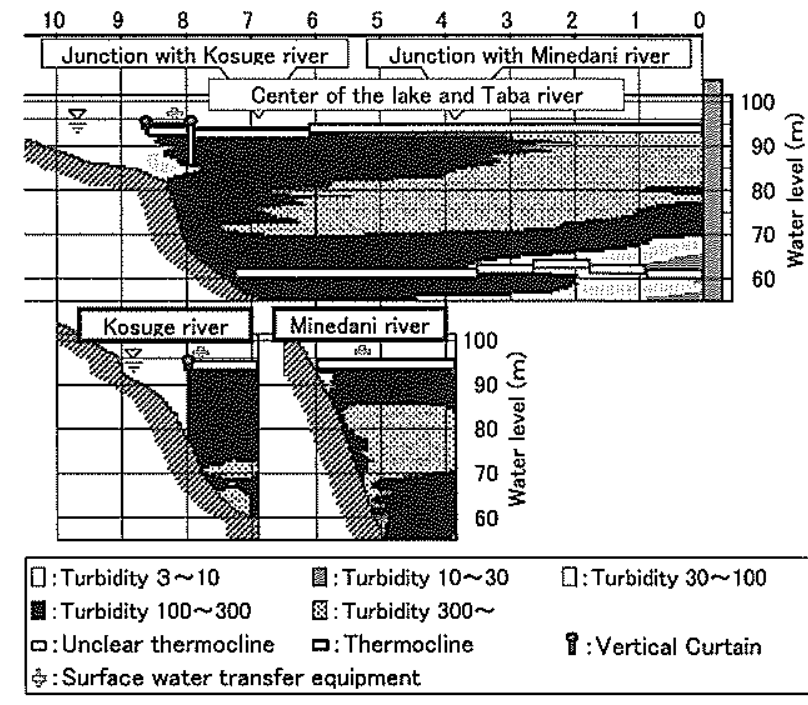

Fig.15 Profile of turbidity after the big freshet (13th Sep)

Distance from the front of dam $(\mathrm{km})$
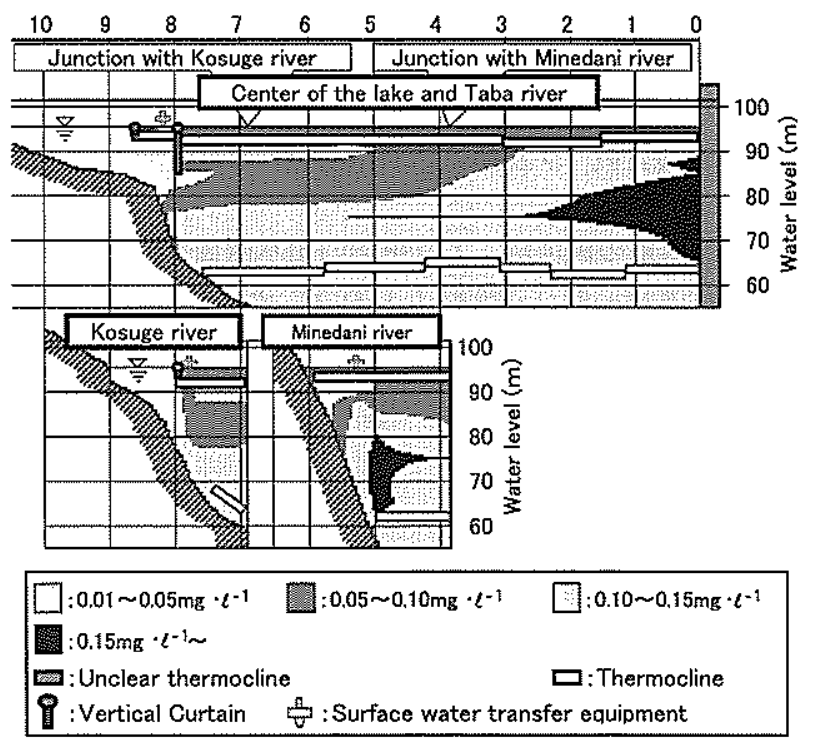

Fig.16 Profile of total phosphorus after the big freshet (13th Sep) 
Distance from the front of dam $(\mathrm{km})$

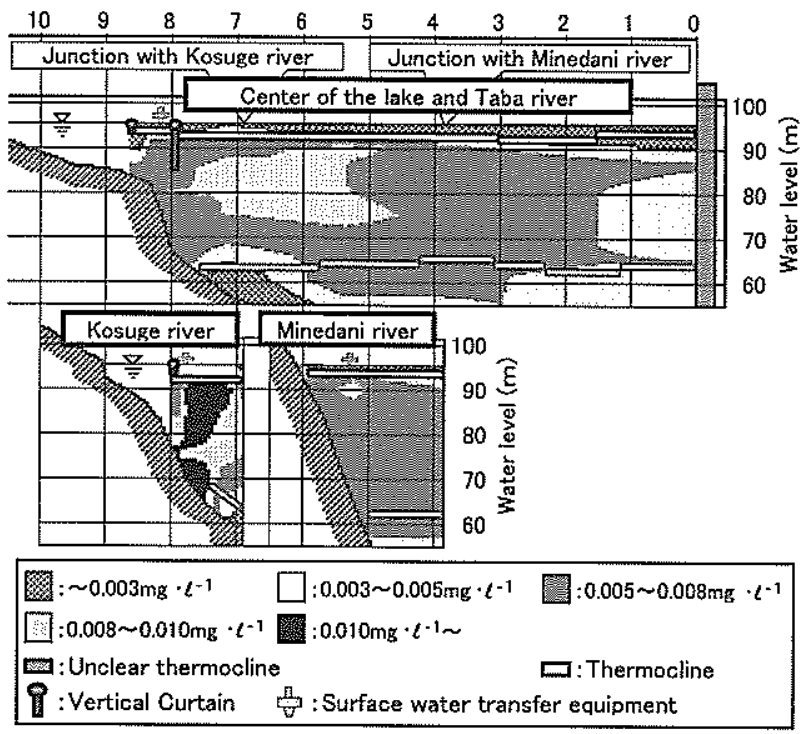

Fig.17 Profile of orthophosphoric acid after the big freshet (13th Sep)

入部の水深 $15 \mathrm{~m}$ から $20 \mathrm{~m}$ 程度を中心に比較的高湄度で分 布していることが分かる。これについては，(1)リン酸態り ンと総リンの貯水池への流入は同特であったが,リン酸態 リンは貯水池内でわずかに残留している櫒類に吸収, ある いは溜質に吸着されたため梌出されなかった，(2)総りンは， 水源林表層の土砂とともに貯水池へ流入したが,リン酸態 リンは土壤を経由して地下浸透水に出たものであること から，貯水池への流入に時間差が生じた，などの理由が考 えられる。引き続き調查の必要があると思われる。

\section{5. まとめ}

平成19年における小河内貯水池の水質調査を実施した。 その結果は，以下のとおりであった。

1) 貯水位は，90m台で推移した。台風等による出水は 4 回あり,このうち 9 月上旬の出水による流入量は, 既往 最大規模であった。

2）ダム前の水温は，眝水位 $60 \mathrm{~m}$ 以媣は年間を通じて概 ね $10^{\circ} \mathrm{C}$ 以下であったが，表層では最高 $27.4^{\circ} \mathrm{C}$ に遵した。

3）水温躍層は, ダム前で最大 3 段, 河川流入部では最 大 4 段形成され, 夕゙ム前の 2 次躍層は，9月上旬の出水に より消滅した。

4) ダム前の濁度は，7月中旬の出水直後を除き，8月 末頃まで全尿に渡り 3 度以下であったが, 9 月上旬の出水
後には， 3 次躍層相当水深まで 100 度以上の濁水が流入し た。この際に流入した濁水は，12月末現在も一部が残留し ている。

5）藍藻類は，8月に河川流入部で藍藻類が観察された が,アオコ形成には至らなかった。

6）力ビ卓原因物質は，藍藻類の出現に伴って河川流入 部で検出されたが，ダム前では検出されなかった。

7）７月中旬に発生した出水後の濁度分布状況から，第 1 フェンス近傍では, 鉛直方向で 2 層に分かれた流れがあ る可能性が示唆された。分画フェンスの機能をより明確に するためには, 河川流入部における湖水の流動之藻類の举 動について調査していく必要がある。

8）大規模出水があった埸合でも濁水を迅速に排除する ためには，出水による流入量を勘案した水深に 2 次躍層を 形成できるような貯水池運用が必要であると考えられた。

9）9月上旬に発生した出水により大墨の滥水が貯水池 へ流入した。この際に流入した濁水は，12月末現在一部が 未だに貯水池内に残留しており，平成20年の春季以降, 水 温の上昇に伴って落類の異常增殖を引き起こす可能性が ある状況となっている。

10）9月上旬の出水後において，総リンは主に湖心部下 流部分に高漴度で分布し、リン酸態リンは主に湖心部上流 部分に高溜度で分布していた。これらの分布状況の違いに ついて，引き続き調查の必要があると思われた。

(原稿受付 2008年 3月29日)

(原稿受理 2008年 8 月22日)

\section{参考文榊}

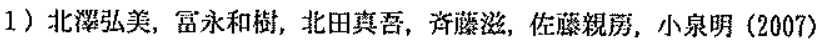

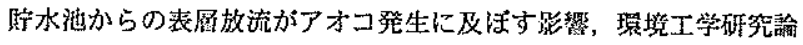
文集, 44,513-524.

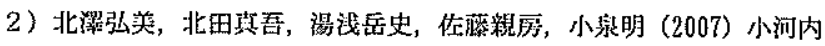

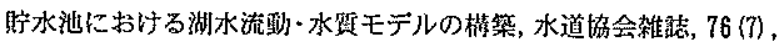
$16-30$.

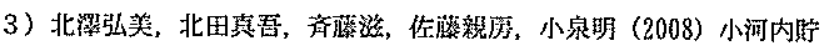
水沲におけるアオコ発生㧕制対策とその效果, 水道協会雑誌, 77 ( $(9)$, $10-24$.

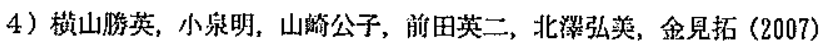
小河内眝水池分画フェンスの水瑟的機能と水質制御について, pp. 112-113，第58回全国水道研究発䒾会請演集 (社) 日本水道招会).

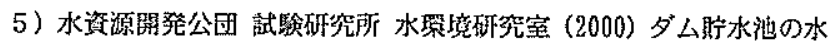
空（2甜版），pp. 35-54，（水资源開発公団）。

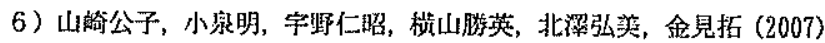
森林河川に与える降雨の影绹, pp. 564-565, 第58回全国水道啡究発 表会㒛演集 ( (社) 日本水道協会). 